\title{
Cardiac arrest due to left circumflex coronary artery embolism as a complication of subtherapeutic oral anticoagulation in a patient with mitral and aortic mechanical valve prostheses
}

Zator gałęzi okalającej lewej tętnicy wieńcowej powikłany nagłym zatrzymaniem krążenia w przebiegu nieskutecznej terapii przeciwkrzepliwej u pacjentki z mechaniczną protezą zastawki mitralnej i aortalnej

\author{
Marcin Protasiewicz, Aleksandra Rojek, Jacek Gajek, Andrzej Mysiak \\ Department of Cardiology, Medical University of Wroclaw, Poland
}

Postep Kardiol Inter 2013; 9, 1 (31): 97-100 DOI: 10.5114/pwki.2013.34034

\begin{abstract}
We report a case of a 65 -year-old female patient after replacement of aortic and mitral valve with mechanical prostheses and implantation of a pacemaker hospitalized in our clinic due to acute coronary syndrome complicated with cardiac arrest due to ventricular fibrillation. The electrocardiogram performed on admission showed signs of myocardial infarction with concomitant ventricular pacing. After successful resuscitation the coronary angiography was performed, which showed occlusion of the left circumflex artery (LCX) by thrombus. On the basis of intravascular ultrasound imaging the presence of vulnerable plaque, parietal thrombus and dissection of LCX were excluded. It suggested that occlusion of the LCX resulted from its embolism by left-sided heart thrombus due to subtherapeutic oral anticoagulation. In this case suboptimal anticoagulation was partially iatrogenic. Two weeks before the patient had been given vitamin $\mathrm{K}$ intravenously due to indeterminable international normalized ratio (INR) level, which caused transient resistance to oral anticoagulants. This case report illustrates tragic difficulties in the treatment with vitamin $\mathrm{K}$ antagonists, which concern as many as $2 / 3$ of anticoagulated patients. These troubles contributed to the search for new, more efficient and safer anticoagulants. There are two classes of new oral anticoagulant drugs, which do not require monitoring of coagulation: direct thrombin inhibitors (e.g. dabigatran) and factor Xa inhibitors (e.g. rivaroxaban). In spite of their proven efficacy in the prevention of ischaemic stroke related to atrial fibrillation and prevention or treatment of deep vein thrombosis and pulmonary embolism, the use of new oral anticoagulants for the treatment of patients with mechanical valve prostheses needs further research.
\end{abstract}

Key words: coronary artery embolism, anticoagulants, valve prostheses.

\section{Streszczenie}

Przedstawiono przypadek 65-letniej chorej po wszczepieniu mechanicznej zastawki mitralnej i aortalnej oraz po implantacji sztucznego stymulatora serca, hospitalizowanej w Klinice Kardiologii z powodu ostrego zespołu wieńcowego powikłanego nagłym zatrzymaniem krążenia w mechanizmie migotania komór. Przy przyjęciu do Kliniki w EKG obserwowano zapis świadczący o zawale mięśnia serca w obrazie stymulacji serca. Po skutecznej resuscytacji pacjentce wykonano koronarografię, w której stwierdzono amputację gałęzi okalającej lewej tętnicy wieńcowej (CX) spowodowaną zakrzepem w świetle naczynia. Na podstawie obrazowania metodą ultrasonografii wewnątrzwieńcowej wykluczono obecność niestabilnych zmian miażdżycowych, zakrzepu przyściennego oraz dysekcji Cx w miejscu jej amputacji. Uznano, że przyczyną zamknięcia Cx był zator materiałem zakrzepowym z lewych jam serca, którego powstanie prawdopodobnie zostało spowodowane nieskutecznym leczeniem przeciwkrzepliwym. W przedstawionym przypadku suboptymalny poziom wskaźnika protrombinowego (international normalized ratio - INR) miał częściowo przyczynę jatrogenną. Około 2 tygodni przed obecnym incydentem sercowo-naczyniowym pacjentka z powodu nieoznaczalnych wartości INR otrzymała dożylnie witaminę K, co spowodowało przejściową oporność na pochodne kumaryny. Przypadek ten jest dramatyczną ilustracją trudności w leczeniu przeciwkrzepliwym, dotyczących nawet 2/3 chorych wymagających takiej terapii. Wymienione trudności potwierdzają zasadność poszukiwania skuteczniejszych, bezpieczniejszych i bardziej przewidywalnych metod profilaktyki przeciwzakrzepowej. Wynikiem tych poszukiwań są aktualnie dwie nowe grupy doustnych leków przeciwkrzepliwych niewymagających monitorowania efektu antykoagulacyjnego.

Corresponding author/Adres do korespondencji:

Aleksandra Rojek MD, Department of Cardiology, Medical University of Wroclaw, 213 Borowska St, 50-556 Wroclaw, tel.: +48 717364220 , e-mail: olarojek@yahoo.com

Received: 9.11.2012, accepted: 21.01.2013. 
Należą do nich: bezpośrednie inhibitory trombiny (dabigatran) oraz inhibitory czynnika Xa (riwaroksaban). Chociaż udowodniono skuteczność wymienionych leków w profilaktyce udaru niedokrwiennego u pacjentów z migotaniem przedsionków oraz profilaktyce i leczeniu żylnej choroby zakrzepowo-zatorowej, bezpieczeństwo ich zastosowania u pacjentów ze sztucznymi zastawkami serca wymaga potwierdzenia $w$ badaniach klinicznych.

Słowa kluczowe: zator tętnicy wieńcowej, antykoagulanty, protezy zastawkowe.

\section{Case report}

A 65-year-old woman with a medical history of heart disease was urgently admitted to the department due to sudden cardiac arrest of ventricular fibrillation. The patient had undergone cardiac surgery in the past (in 2004) because of complex mitral valve disease with predominance of regurgitation. The procedure of prosthetic mitral valve implantation (SJM-29 valve) was accompanied by a prosthetic aortic valve implantation (SJM-21 valve) due to moderate stenosis of the valve and tricuspid valvuloplasty due to significant regurgitation of the valve. Valvular dysfunctions did not coexist with coronary artery disease. Left ventricular systolic function before the procedure was depressed (ejection fraction 35\%). Because of symptomatic bradycardia accompanying persistent atrial fibrillation the patient also underwent a VVI type pacemaker implantation (in 2004). The patient has also had some oncological history. She underwent left side nephrectomy and extirpation of the uterus with appendages due to ovarian and renal cancer (in 2010). In November 2011 the patient suffered from low-risk pulmonary embolism. Difficulties with pharmacological control of the heart rhythm with concomitant European Heart Rhythm Assiociation (EHRA) class IV symptoms were the reasons for performance of a successful conductance modification through the atrioventricular node by means of RF ablation done in September 2011. After the procedure the heart rhythm remained at about $70 \mathrm{bmp}$ with ventricular pacing comprising $40-50 \%$ of beats. Because of this fact as well as significantly depressed left ventricular systolic function with ejection fraction of $25 \%$ the patient was also qualified for resynchronization therapy by an upgrade of the existing device. Coronary angiography performed during this hospitalization did not show atherosclerotic changes in coronary arteries. Due to a previous episode of pulmonary embolism and other medical history, an oncological examination was ordered before the introduction of resynchronization therapy. It did not demonstrate any signs of cancer recurrence or dissemination. The presence of prosthetic heart valves, a previous episode of pulmonary embolism and atrial fibrillation were the reasons for chronic anticoagulation with vitamin $\mathrm{K}$ antagonists. The therapy was difficult because of labile international normalized ratio (INR) values. An immeasurable INR value without signs of clinically overt bleeding was observed in December 2011 during the patient's hospitalization on the internal ward due to stomach pain and loss of appetite. At that time she was treated with intravenous administration of $10 \mathrm{mg}$ of vitamin K. The abrupt drop of prothrombin level was probably caused by depressed liver synthesis of coagulation factors and decreased absorption of vitamin $\mathrm{K}$ caused by retention of blood in the organs of the abdominal cavity secondary to decompensating heart failure. After the pharmacological intervention INR values decreased to 1.18 and were the starting point of approximately 2 weeks of transient (warfarin) resistance.

In the present case the diagnosis of ventricular fibrillation was made by an ambulance crew at the patient's home. Ventricular fibrillation, successfully terminated by defibrillation, reoccurred several times. Electrocardiogram registered after defibrillations showed signs of myocardial infarction within the paced rhythm (Figure 1). The patient was intubated and mechanically ventilated. After reaching the hos-

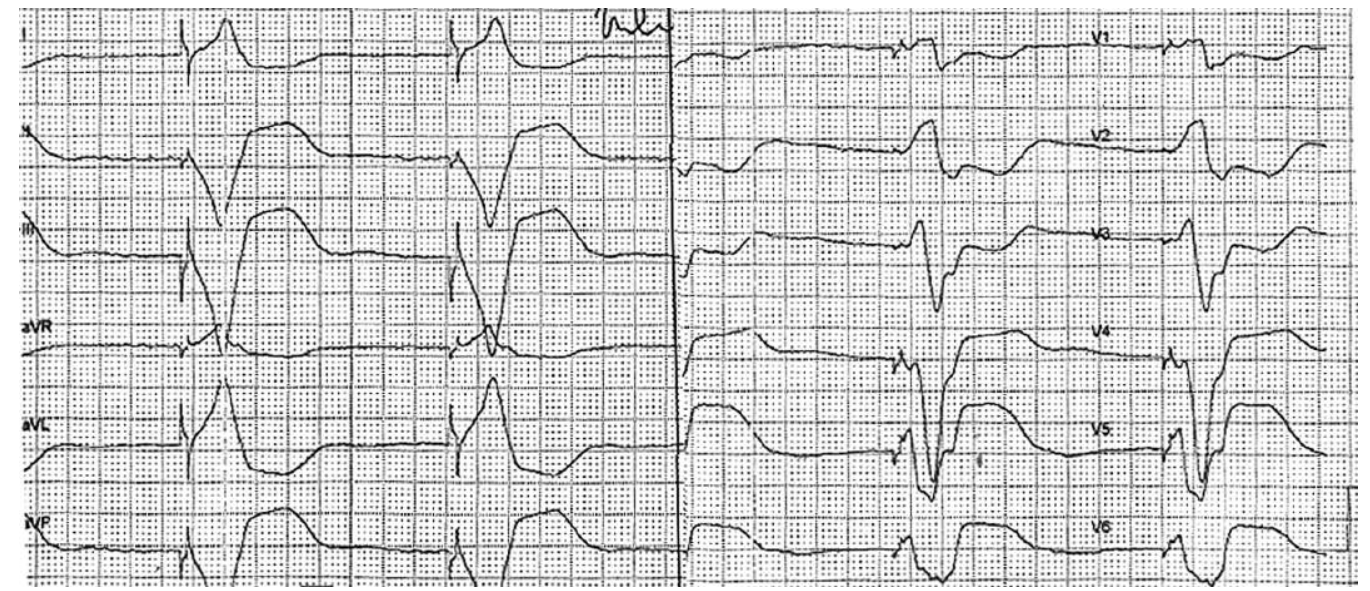

Fig. 1. Electrocardiogram performed on admission

Ryc. 1. Elektrokardiogram zarejestrowany przy przyjęciu 


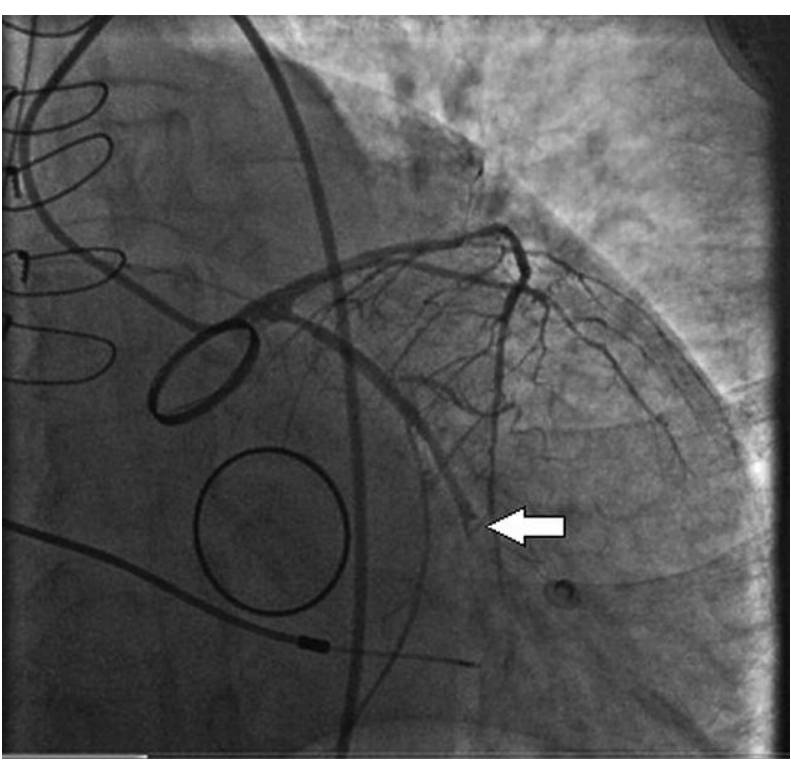

Fig. 2. Angiogram of left coronary artery (the arrow shows occlusion of $\mathrm{LCX}$ )

Ryc. 2. Angiografia lewej tętnicy wieńcowej (strzatka wskazuje miejsce amputacji gatęzi okalającej)

pital she was transferred from the ER directly to the catheterization laboratory.

The patient had a paced rhythm of $70 \mathrm{bmp}$, and arterial blood pressure of 100/60 $\mathrm{mm} \mathrm{Hg}$ after infusion of catecholamines (dopamine at $8 \mu \mathrm{g} / \mathrm{kg} / \mathrm{min}$ ). Laboratory examinations demonstrated leukocytosis (12.87 thousand/ $\mu \mathrm{l})$, slight normocytic anemia (hemoglobin $11.6 \mathrm{~g} / \mathrm{dl}$ ), increased levels of D-dimers $(9.38 \mu \mathrm{g} / \mathrm{ml})$, creatinine $(1.57 \mathrm{mg} / \mathrm{dl})$, potassium $(5.84 \mathrm{mmol} / \mathrm{l})$ and troponin I $(0.033 \mathrm{ng} / \mathrm{ml})$. International normalized ratio was 2.18 .

Coronary angiography showed the occluded large circumflex artery (CX) with lack of significant lesions in the other coronary arteries. Angiography suggested the presence of $C x$ occlusion caused by arterial thrombus (Figure 2 ). This suspicion led to the use of aspiration thrombectomy as the first choice (Export Catheter 6 F). After three passages with the aspiration catheter, its retraction to the guiding catheter under constant vacuum and aspiration of blood from the guiding catheter, several macroscopically visible, large fragments of red thrombus were demonstrated (Figure 3). Contrast administration to the left coronary artery showed total recanalization of the circumflex artery with normal flow to the peripheries of the vessel. At the same time there were no atherosclerotic changes at the site of previous artery occlusion (CX/Mol bifurcation). Intravascular ultrasound (IVUS) of the circumflex and marginal arteries was done to exclude dissection as a cause of acute arterial thrombosis. The images from IVUS confirmed the presence of insignificant, stable atherosclerotic lesions without damage to the vascular wall (Figure 4). No signs of residual peri-mural thrombus were observed. After successful opening of the artery the patient's condition gradually improved, and arterial blood pressure rose

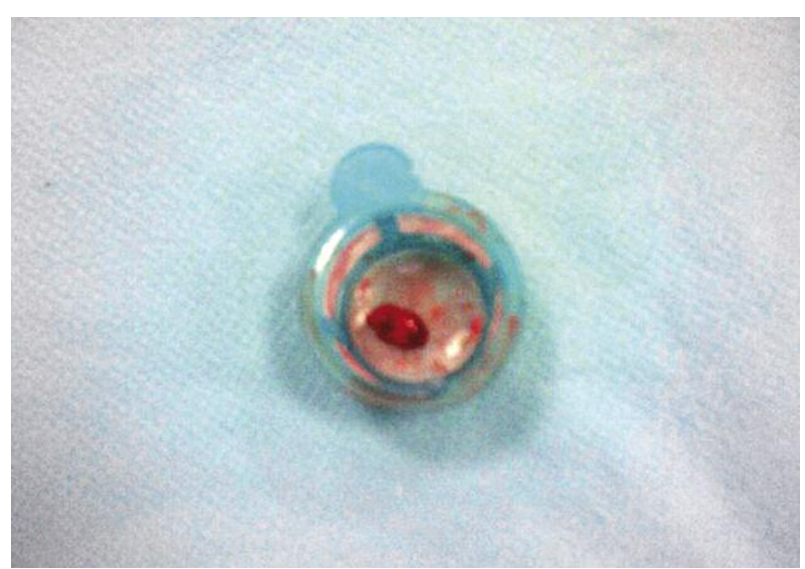

Fig. 3. The thrombus aspirated from LCx

Ryc. 3. Zakrzep zaaspirowany z gatęzi okalającej lewej tętnicy wieńcowej

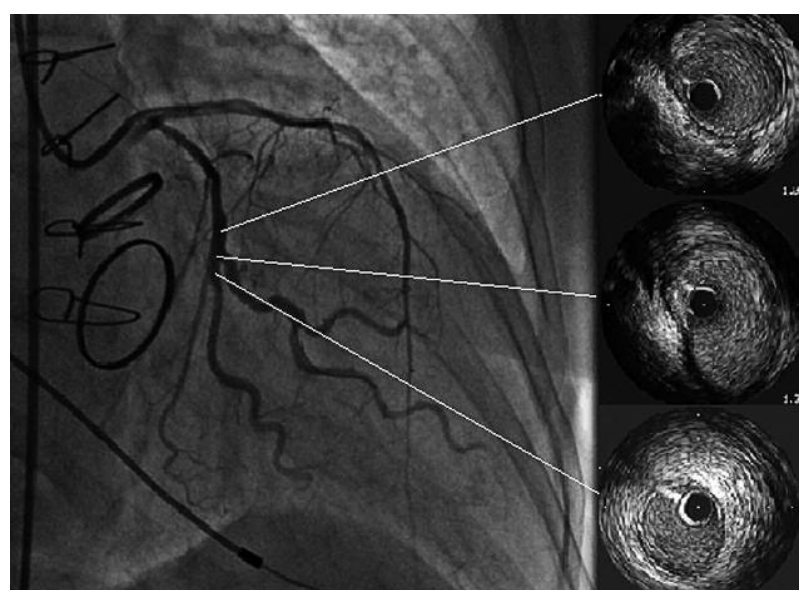

Fig. 4. Angiogram and intracoronary ultrasound of left coronary artery after thrombectomy

Ryc. 4. Angiografia i ultrasonografia wewnątrznaczyniowa lewej tętnicy wieńcowej po zastosowaniu trombektomii

to $120 / 70 \mathrm{~mm} \mathrm{Hg}$. The patient was transferred to the intensive care unit. Transesophageal echocardiography did not reveal the presence of embolic material on the heart valves or in the left atrial appendage. However, a spontaneous echo contrast of blood in the heart chambers was observed. Because of stable ECG catecholamine infusion was reduced on the next day and then completely stopped together with sedation discontinuation. Subsequently the patient was extubated. There were no neurological deficits observed as the patient regained consciousness. She remained in a stable hemodynamic condition.

Due to persistence of class III/IV symptoms of heart failure despite optimal pharmacotherapy, the presence of signs of electric dyssynchrony (QRS $140 \mathrm{~ms}$ ) and normal results of oncological examination the patient was qualified for cardiac resynchronization therapy. 


\section{Discussion}

Despite the lack of thrombotic material on prosthetic valves or in the left atrium on transoesophageal echocardiography we decided that the most likely reason for circumflex artery occlusion was embolic material originating from the left heart chambers. Inadequate control of INR and its non-therapeutic values after the use of intravenous vitamin $\mathrm{K}$ might have been a cause of thrombotic material generation. Medical documentation delivered to the hospital showed INR values between 1.18 and 1.12 during the period of 10 days preceding the current hospitalization. Embolic aetiology of the presented cardiovascular incident was also suggested by the lack of atherosclerotic changes in coronary arteries including particularly a lack of unstable plaque, dissection or peri-mural thrombus.

Ineffective antithrombotic therapy is an important therapeutic problem concerning up to $2 / 3$ of patients requiring this type of treatment [1]. International normalized ratio values in patients chronically treated with oral anticoagulants are outside the therapeutic range for $34-60 \%$ of the time [2, 3]. Vitamin $\mathrm{K}$ antagonists have a relatively narrow therapeutic window and their use is subject to obligatory and regular monitoring of coagulation parameters, which increases the costs of therapy and influences the patient's quality of life. These difficulties led to the search for more effective, safer and more predictable methods of thromboprophylaxis. This research resulted in development of 2 new groups of oral anticoagulant drugs having different mechanisms of action and not requiring anticoagulation effect monitoring, i.e. direct thrombin inhibitors (dabigatran and ximelagatran, which was withdrawn because of hepatotoxicity) and factor Xa inhibitors (rivaroxaban, apixaban, betrixaban). Dabigatran was shown to be effective in the prevention of ischaemic strokes in patients with atrial fibrillation (RE-LY study) [4], in the prevention of primary deep venous thromboembolism (DVT) (RE-NOVATE, RE-NOVATE II) $[5,6]$, in the treatment of symptomatic DVT (RE-COVER, RE-COVER II) [7] and in the prevention of secondary DVT (RE-MEDY, RE-SONATE) [8]. Despite that, according to the most recent update [9], the drug is not effective enough in patients with prosthetic heart valves (also in patients with renal or liver failure). Other drugs such as rivaroxaban are also not indicated as antithrombotic treatment in patients with prosthetic heart valves.

The present case is a dramatic illustration of difficulties related to antithrombotic treatment. It may be assumed that these types of therapeutic problems are partially iatrogenic. Vitamin $\mathrm{K}$ administration in case of oral anticoagulant overdosing may lead to long lasting resistance to vitamin $\mathrm{K}$ antagonists with its very serious consequences. Intravenous administration of vitamin $\mathrm{K}$ should be limited to patients with significant and life-threatening bleeding irrespectively of the INR values. In the present case the intervention could possibly have been limited to oral vitamin $\mathrm{K}$ supplementation at a lower dose and temporary withdrawal of the antithrombotic drug. However, given the frequency of emerging difficulties in maintaining the desired effects of antithrombotic treatment, it is particularly important to continue research on new drugs also in patients with prosthetic heart valves. The currently ongoing phase II clinical trial REALIGN assesses the efficacy of dabigatran in comparison to warfarin in patients with prosthetic mitral or aortic valve; the project should end in 2018.

\section{References}

1. Rewiuk K, Bednarz S, Faryan P, Grodzicki T. Knowledge of antithrombotic prophylaxis among patients with atrial fibrillation. Cardiol J 2007; 14: 44-49.

2. Rose AJ, Ozonoff A, Grant RW, et al. Epidemiology of subtherapeutic anticoagulation in the united states. Circ Cardiovasc Qual Outcomes 2009; 2: 591-597.

3. Gurwitz JH, Monette J, Rochon PA, et al. Atrial fibrillation and stroke prevention with warfarin in the long-term care setting. Arch Intern Med 1997; 157: 978-984.

4. Camm AJ. Randomized evaluation of long-term anticoagulant therapy: dabigatran vs. warfarin. Eur Heart J 2009; 30: 2554-2555.

5. Eriksson BI, Dahl OE, Huo MH, et al.; Group R-NIS. Oral dabigatran versus enoxaparin for thromboprophylaxis after primary total hip arthroplasty (RE-NOVATE*). A randomised, double-blind, noninferiority trial. Thromb Haemost 2011; 105: 721-729.

6. Eriksson BI, Dahl OE, Rosencher N, et al.; Group R-NS. Dabigatran etexilate versus enoxaparin for prevention of venous thromboembolism after total hip replacement: a randomised, doubleblind, non-inferiority trial. Lancet 2007; 370: 949-956.

7. Constantinescu MC. Dabigatran is as effective as warfarin in the treatment of acute venous thromboembolism: the re-cover study. Maedica (Buchar) 2010; 5: 77-78.

8. Schulman S. Treatment of venous thromboembolism with dabigatran. Curr Opin Pulm Med 2012.

9. Wann LS, Curtis AB, Ellenbogen KA, et al.; Force ACoCFAHAT. 2011 ACCF/AHA/HRS focused update on the management of patients with atrial fibrillation (update on dabigatran): A report of the American College of Cardiology Foundation/American Heart Association task force on practice guidelines. Circulation 2011; 123: 1144-1150. 